\title{
Problems Caused by Thermal Bridges around Windows of Historic Buildings and Renovation Methods
}

\author{
C. Tömböly
}

\author{
Budapest University of Techncology and Economics, \\ Department of Construction Materials and Technologies \\ Müegyetem rkp. 3, H-1111 Budapest, Hungary \\ Phone: +36 14633070 \\ e-mail: tomboly.cecilia@epito.bme.hu
}

\begin{abstract}
Preserving the old forms and structural details in case of renovation of buildings is a primary issue. The structure of traditional wooden windows, as eyes of the building, defines the character of the facade, the street view and also influences the character of the whole townscape. With the new building energy regulations energy awareness became conspicuous, which is current requirement during the energy crisis of the XXI. century at national and international levels as well. This paper investigates all the renovation or replacement methods of historic windows should be considered.
\end{abstract}

Keywords: energy-conscious design, historic windows, thermal performance, thermal insulation capability of windows, renovation

\section{Introduction}

The building stocks of the city center of Budapest and other Hungarian cities were mainly built at the turn of the century or before, and a significant amount of them have impressive façades. Beside them, in the country there are many castles, palaces, and country houses with different architectural style. According to the data released by the Hungarian Central Statistical Office in 2003, residential buildings can be grouped according to the date of construction as the following: $10 \%$ in 1989 and $17 \%$ in 1980 $89.23 \%$ in $1970-79,15 \%$ of $1960-69,12 \%$ in $1945-58,12.5 \%$ in $1920-45$, and $10.5 \%$ were built before 1920. It means nearly one million historic structures, and the renovation of their fenestrations is a main priority, with often preserving the inner appearance.

Instead of preserving the old forms, new characterless windows are often installed in historic buildings. The main functions of windows is to let the light in, provide air exchange and, secondly, they have to fulfill thermal and acoustic requirements. Since windows are complex structures, and they are exposed to climatic effects, their 
renovations have to be executed with attention. The owners have to be aware of the fact that although the reconstruction usually takes longer than the installation of a new structure, but the payback period is significantly shorter. [1]

Unfortunately, due to lack of expertise, the proper renovation of historic windows is not common, since manufacturers suggest that new products with advantageous characters are better and more modern in all cases. Old structures are often taken out and replaced by plastic windows; however, they would have been renovated and restored in many cases. The replacement causes serious damage to the character of a historic building, as well as contributes to a large amount of waste, that - from sustainability aspect - should be reused to avoid environmental contamination. [2]

\section{Historic windows}

The evolution of windows looks back hundreds of years. In the Baroque the windows were usually single-layered. During the classicism outward-inward opening windows with double glass layers were also applied. Since about 1855 double glazed windows with inward-inward openings appeared, but they were developed to a perfect level later in Historicism. During Secession, beside the technical knowledge, there was no limit for formal variations (Chart 1). We can conclude that these windows are style carriers, i.e. they are connected to certain architectural styles. Based on the size and forms, the age of a window can be determined with 10-20 years accuracy.

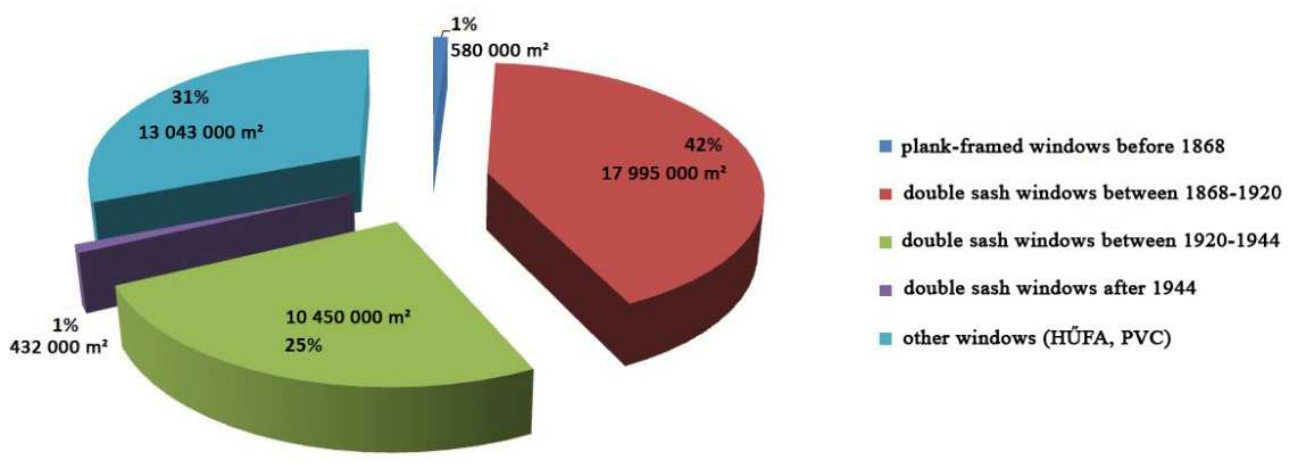

Figure 1. Windows supposed to be renovated in Hungary [3]

In Hungary the historic windows can be grouped as plank-framed and double sash windows. (Figure 2). The plank-framed windows are usually found in historical buildings, and during a renovation the original forms should be saved. The double sash windows are found in a significant number of houses in Budapest and other larger cities, where the forms are the integral part of the historic cityscape. Therefore, it would be important to develop a reconstruction technology that keeps the old forms and structural design, and also meets the new technical requirements. 

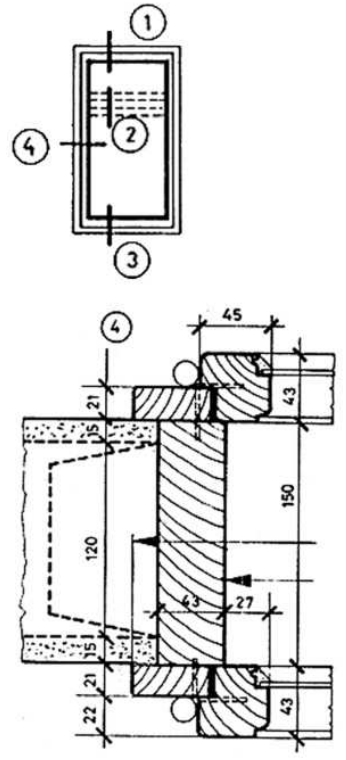

(2)

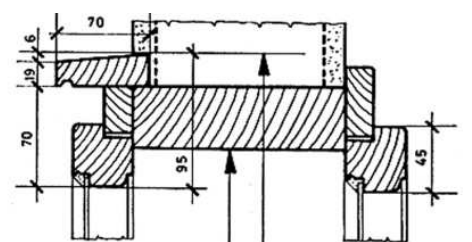

(3)

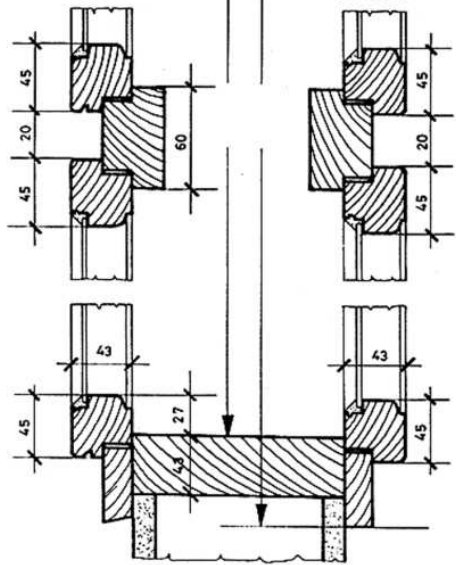

(1)

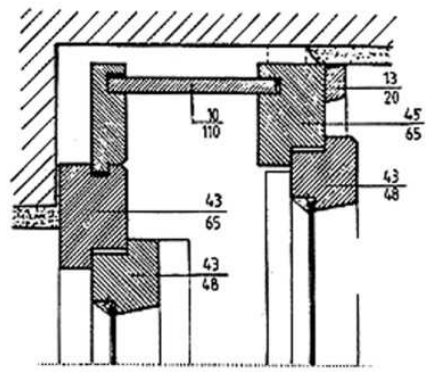

(3)

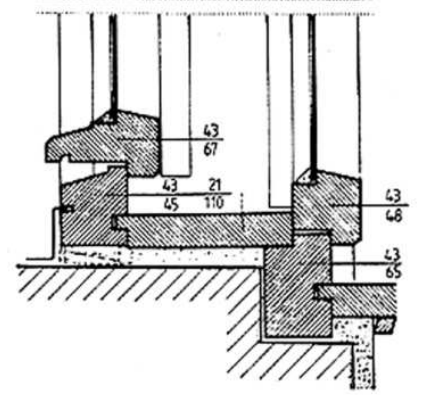

Double sash window

Plank-framed window

Figure 2. Details and sizes of plank-framed and double sash windows [4]

\section{Calculation of thermal performance of windows and doors}

During a reconstruction, decreasing the heat loss at surfaces increases the effect of thermal bridges. If the exterior walls are thermally insulated, the thermal bridges at beams above fenestrations increases. Therefore, during a renovation, instead of dealing with details, a holistic approach is necessary [5].

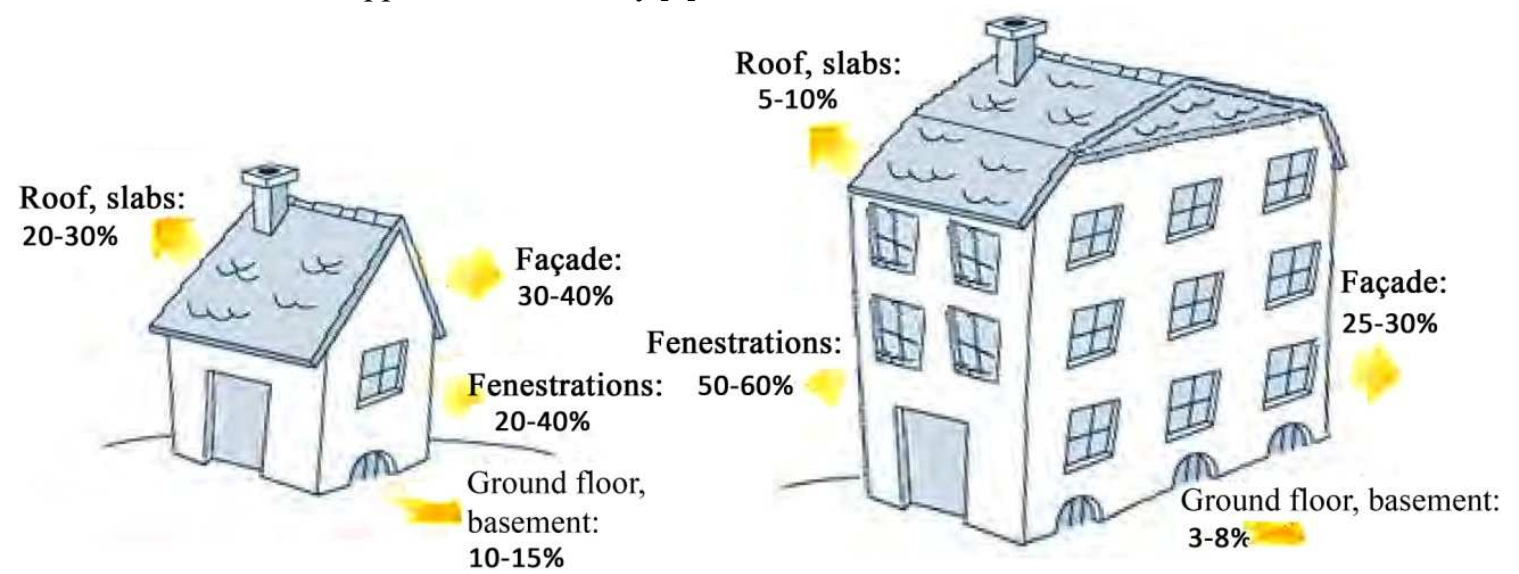

Figure 3. Heat loss at different surfaces [6,7] 
Normally, doors and windows show less resistance to heat flow than other parts of the building. [8] During calculations the additional heat loss at thermal bridges is taken into account with the linear thermal transmittance, therefore the resulting heat transfer coefficient of a wall with windows [9]:

$$
U_{e}=\frac{A_{\text {wall }} U_{\text {layer }}+\sum_{j} l_{j} \psi_{j}}{A}
$$

The heat transfer coefficient of a single pane window - $U_{\mathrm{w} .1}-$ can be calculated by the following formula (Figure 4.):

$$
U_{w .1}=\frac{A_{G} U_{G}+A_{F} U_{F}+l_{G} \psi_{G}}{A_{G}+A_{F}} \quad\left\lceil\mathrm{~W} / \mathrm{m}^{2} \mathrm{~K}\right\rceil\lceil 10,11\rceil
$$

where:

$\mathrm{U}_{\mathrm{w} .1}\left[\mathrm{~W} / \mathrm{m}^{2} \mathrm{~K}\right]$ heat transfer coefficient of the whole window structure

$\mathrm{A}_{\mathrm{G}}\left[\mathrm{m}^{2}\right] \quad$ surface of the glass pane (the smaller from the inner and outer panes)

$\mathrm{U}_{\mathrm{G}}\left[\mathrm{W} / \mathrm{m}^{2} \mathrm{~K}\right]$ heat transfer coefficient of the glass pane

$\mathrm{A}_{\mathrm{F}}\left[\mathrm{m}^{2}\right] \quad$ area of the frame (inner side if the window is closed, or from the outer side the larger value from the common area of the frame and the window sash)

$\mathrm{U}_{\mathrm{F}} \quad\left[\mathrm{W} / \mathrm{m}^{2} \mathrm{~K}\right]$ heat transfer coefficient of the frame

$l_{G} \quad[\mathrm{~m}] \quad$ Perimeter of glass pane (larger one from the inner and outer perimeters)

$\psi_{G}[\mathrm{~W} / \mathrm{mK}]$ linear thermal transmittance of the glass pane
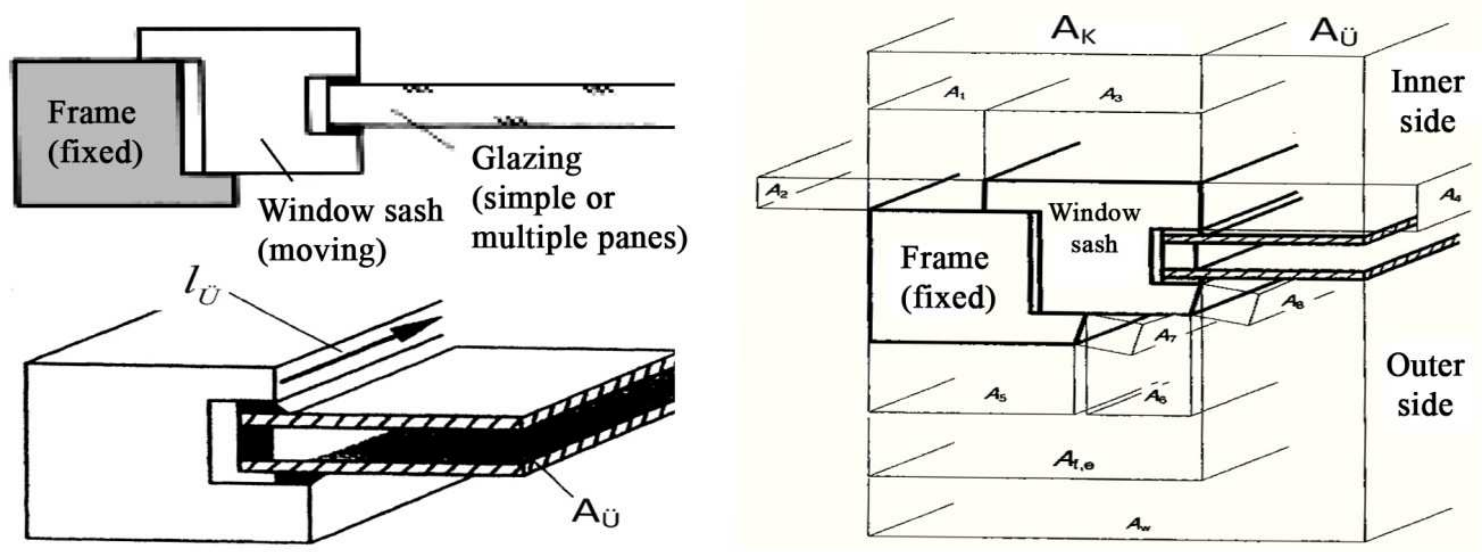

Figure 4. Different surfaces of window structures 
For double paned windows - including the double sash fenestrations - the external and internal structures as well as the effect of the air gap in-between must also be considered. The heat transfer coefficient - $U_{\mathrm{w} .2}$ - can be calculated by the following formula:

where:

$$
U_{w .2}=\frac{1}{\frac{1}{U_{w . e}}-R_{e}+R_{\text {airgap }}-R_{i}+\frac{1}{U_{w . i}}} \quad\left[\mathrm{~W} / \mathrm{m}^{2} \mathrm{~K}\right][12]
$$

$\mathrm{U}_{\mathrm{w} .2}\left[\mathrm{~W} / \mathrm{m}^{2} \mathrm{~K}\right]$ heat transfer coefficient of the whole window structure

$\mathrm{U}_{\mathrm{w.e}}\left[\mathrm{W} / \mathrm{m}^{2} \mathrm{~K}\right] \quad$ heat transfer coefficient of the outer window structure

$\mathrm{U}_{\mathrm{w} . \mathrm{i}}\left[\mathrm{W} / \mathrm{m}^{2} \mathrm{~K}\right]$ heat transfer coefficient of the inner window structure

$\mathrm{R}_{\mathrm{e}} ; \mathrm{R}_{\mathrm{i}}\left[\mathrm{m}^{2} \mathrm{~K} / \mathrm{W}\right]$ thermal resistance of the internal and external glazing, not considering the other layer (these should be considered, if they are used independently)

$\mathrm{R}_{\text {airgap }}\left[\mathrm{m}^{2} \mathrm{~K} / \mathrm{W}\right] \quad$ thermal resistance of the airgap

In order to achieve accurate results of calculations for a certain structure, the following conditions must be considered:

- Precise geometric survey

- Determination of the correct specifications based on available literature.

\section{Methods of value-added renovations of historic windows}

The requirement (which is required for the heat transfer coefficient) was " $\mathrm{k} " \leq 3.0$ $\left[\mathrm{W} / \mathrm{m}^{2} \mathrm{~K}\right]$ for windows and balcony doors between 1979 and 1991. A double sash window in good condition or a composite window can fulfill this requirement. This value may degrade due to the effect of filtration as function of deterioration. However, even if the filtration is decreased, i.e. the window is air-tight, better than this value cannot be reached. There was no requirements for the heat transfer coefficient of windows between 1991 and 2006. From 2006 September the TNM 7/2006 regulation provides mandatory requirements for heat transfer coefficients of windows and doors, the values are listed in following table (Figure 5.):

\begin{tabular}{|l|c|}
\hline Type of fenestration & $\begin{array}{c}\boldsymbol{U}_{\max } \\
\left(\boldsymbol{W} / \boldsymbol{m}^{2} \mathbf{K}\right)\end{array}$ \\
\hline Glazed fenestration on facade (wooden or PVC frame) & $\mathbf{1 . 6 0}$ \\
\hline Glazed fenestration on facade (metal frame) & $\mathbf{2 . 0 0}$ \\
\hline Fenestration on facade, if its area is smaller than $0.5 \mathrm{~m}^{2}$ & $\mathbf{2 . 5 0}$ \\
\hline Glass wall on facade & $\mathbf{1 . 5 0}$ \\
\hline
\end{tabular}

Figure 5. Heat transfer coefficients of different types of windows and doors [13] 
Therefore, in case of renovation of historic windows and doors, the goal is to fulfill the energy requirements of the new regulation, i.e. the heat transfer coefficient for fenestrations with wooden frames should be $U_{w}<1.6 \mathrm{~W} / \mathrm{m}^{2} \mathrm{~K}$.

In case of existing windows these values are cannot be reached only by increasing the air tightness. More serious intervention is needed not only at joints, but also at the whole structure.

The heat transfer coefficient of a window with two glass panes without shadings (without shutters or blinds) - if it not warped and the seal is in good condition - is about $2.2 \mathrm{~W} / \mathrm{m}^{2} \mathrm{~K}$. It largely depends on the size of the glass surface relative to the wooden frame, since the wooden frame itself has very good thermal insulation capability. Thus, in case of a $50 \%$ glass/frame ratio, the $U_{w}$ is $2.05 \mathrm{~W} / \mathrm{m}^{2} \mathrm{~K}$, while if the glass is $65 \%$ or more, it is $2.35 \mathrm{~W} / \mathrm{m}^{2} \mathrm{~K}$. [2] Beside this, the filtration has a significant impact as well, i.e., heat loss associated with outgoing air. In many cases, it is more important than insulating glazing, therefore it is important to seal the joints to avoid filtration[14].

Possible methods of value-added renovations are the following:

\subsection{Installing additional glass pane}

An additional glass pane to the existing window sash can be a solution. In this case the existing window sash has to be in good condition structurally, or it should be strengthened to bear the increased burden.
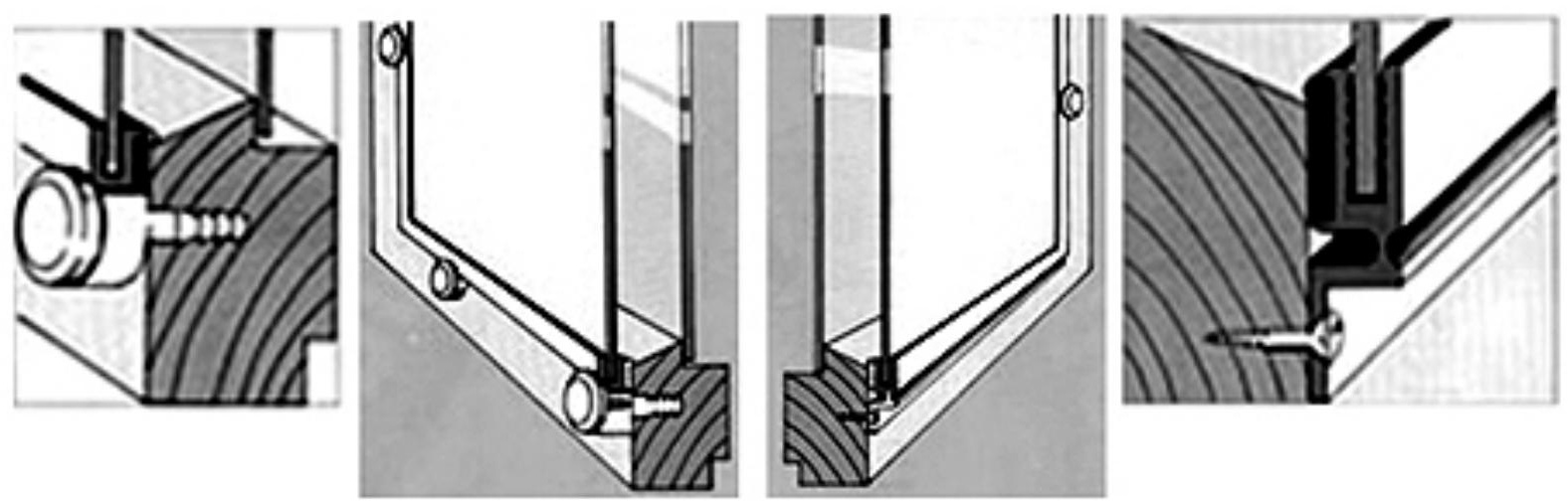

Figure 6. Additional glass pane to an existing window sash, point by point and linear (stiffer) fixing [15]

\subsection{Modification of an existing window sash}

Structural modification of an existing window sash can make it possible to install an insulating glazing with two or three glass layers. In this case the window sash also has to be in good condition structurally, or it should be strengthened to bear the increased burden. 

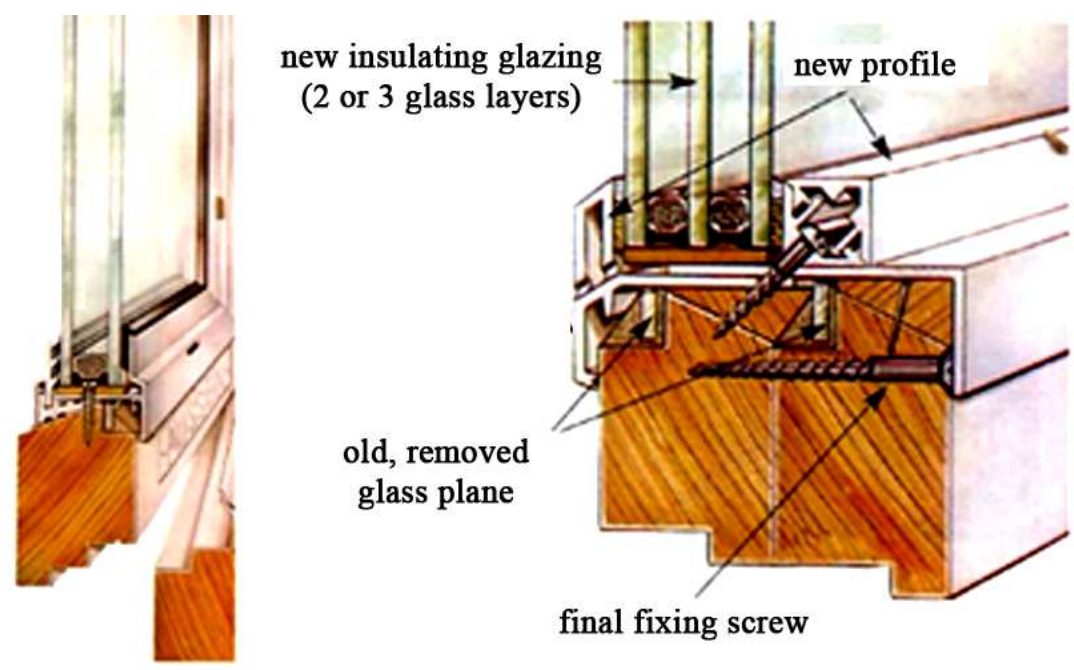

Figure 7. Modification of an existing window sash, with possible strengthening in case of installation of insulating glazing with two or three glass layers [15]

\subsection{Making a new window sash with insulating glazing to the existing frame}

The most common solution in case of double sash windows is to replace the glass panes of the internal window sash with insulating glazing. However, in this case, the increased weight of the glazing can be a problem. In most cases limited layer thicknesses (e.g. 3-6$3 \mathrm{~mm}$ ) and thicker sash profile than the original one, but thinner than the ones being usual today can lead to a compromise. The suspensions should also be strengthened, and in case of bigger windows, it might be necessary to strengthen the frame as well. (Figure 8).

Similar but perhaps even more combined solutions can be applied in case of plankframed windows.

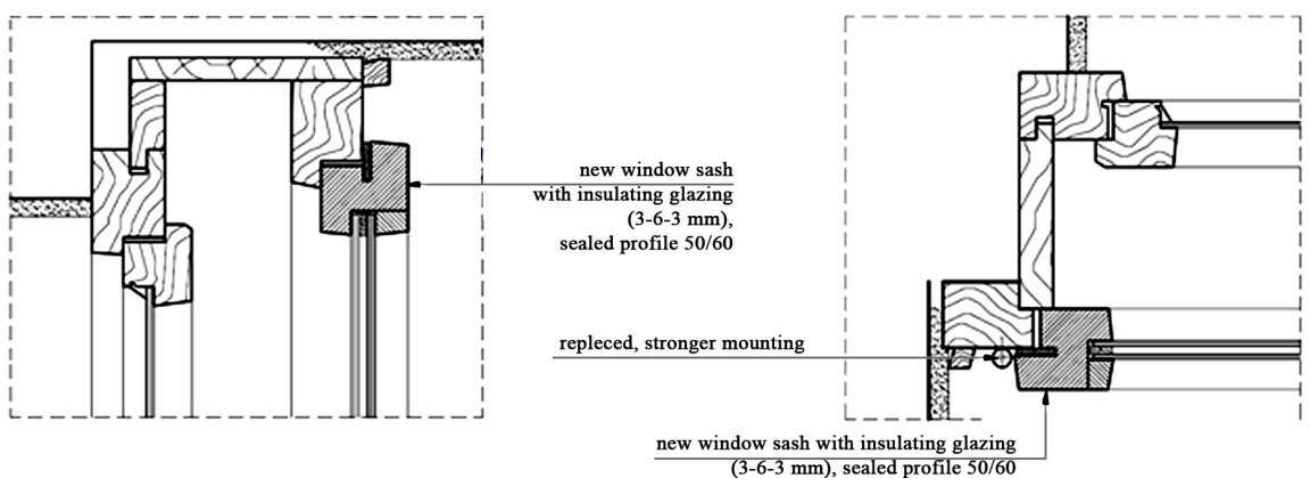

Figure 8. Retrofitting of a double sash window with replacement of the inner window sash with insulating glazing [15] 


\subsection{New window sash with insulating glazing installed into the existing frame structure}

In case of multi-apartment buildings, if the fenestrations are not renovated in the same time, the replacement of the internal window sashes or the internal glass panes are the only acceptable methods of renovation. This corresponds to the theoretical solutions. The outer structure may remain in its original condition. However, it is questionable, what the heat transfer coefficient of the new interior sash should be, and how it should be achieved.

Figure 9. Existing frame structure
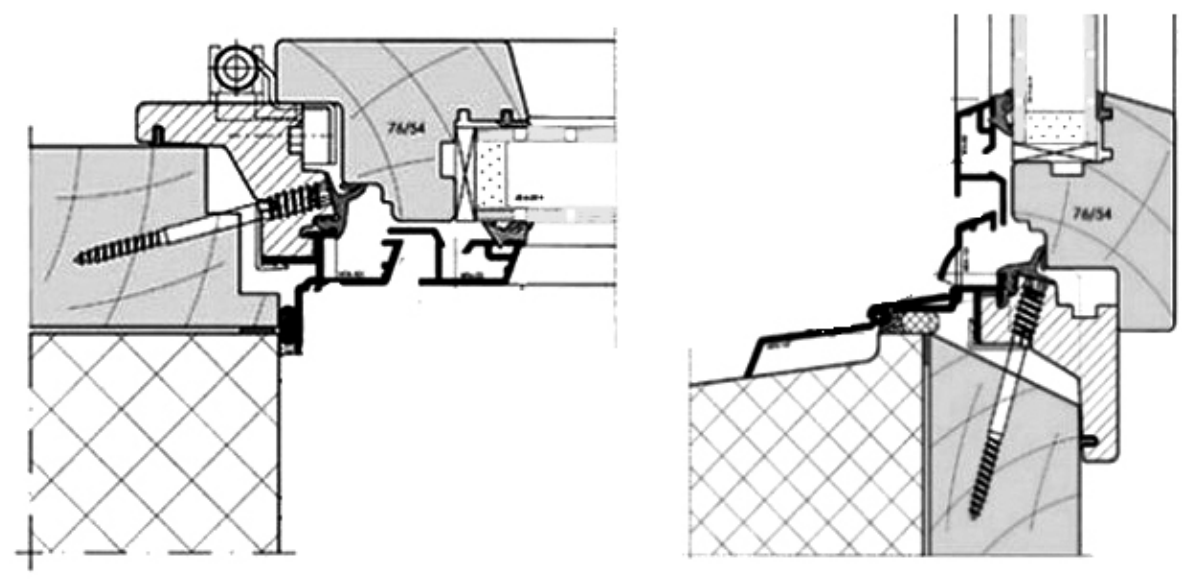

+ frame overlay and new window sash with insulating glazing [15]

\subsection{Low-e glass}

In case of the retention of existing windows, and the glass panes of the internal sash are replaced with a glass pane with hard low-e coating (low-radiation, invisible, with a thin layer of silver), and it is sealed at joints, we can significantly reduce radiated heat loss between the two glass layers. The low-e glass with hard coating (pyrolytic) is not vulnerable, therefore it can be used as a single layer, thus, the original sash structure does not require any changes. The new window $U_{w}$ value will be around 1.8 to $1.9 \mathrm{~W} / \mathrm{m}^{2} \mathrm{~K}$, which almost meets the required $1.6 \mathrm{~W} / \mathrm{m}^{2} \mathrm{~K}$ limit. This case is the least expensive solution, since the window is not modified, and the appearance does not change [16].

A more efficient result can be achieved by a special glazing developed in Western Europe. It has a total thickness of 10 to $14 \mathrm{~mm}(3-4-3,3-7-4)$ and it applies Histoglass D10, D14 glass panes, and the $\mathrm{U}_{\mathrm{w}}$ is between 1.3-1.5 W/m $/ \mathrm{m}^{2} \mathrm{~K}$ (Figure 7.). This would result in minimal increase of the window sash, but it can be installed into existing windows sash as well, since the size of groove of the opening sash is usually 10 to 15 $\mathrm{mm}$. In order to increase the thermal performance, the inner window sash can be strengthened, and with a 4-16-4 glazing the $\mathrm{U}_{\mathrm{w}}$ can achieve $0.9-1.0 \mathrm{~W} / \mathrm{m}^{2} \mathrm{~K}$ (Figure 10.). 


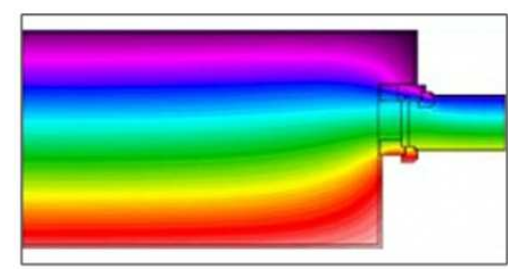

original state

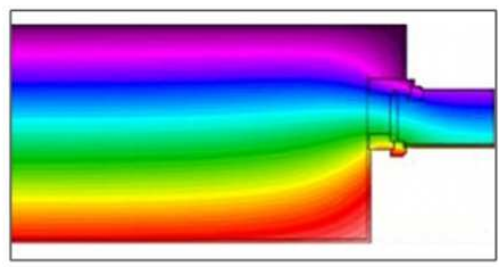

3-6-3 glazing, low-e, gas filling

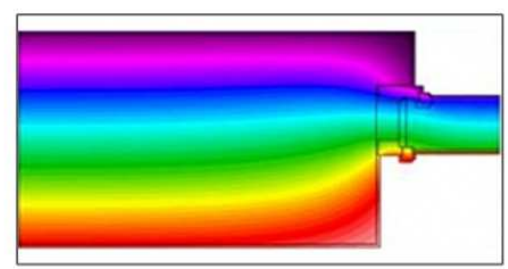

3-4-3 glazing, low-e, gas filling

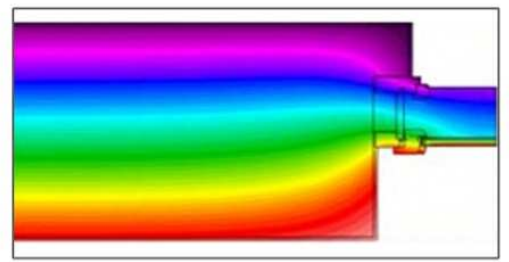

replacement of window sash: 4-16-4 glazing, low-e, gas filling

Figure 10: Isotherms of a double sash window after renovation [17]

From structural and aesthetic point of view, these are also the best solutions. In this case the entire original window structure is retained, and the outer window sash provides an additional thermal insulation. Thus, the three layers of glass - the glazing outside and the inner double layers - already have a significantly better heat transfer coefficient than a new single pane window.

\subsection{Increased thermal insulation requirements}

In case of the renovation of a 2 layers window, if air-filled insulating glazing is placed into the exterior as well as into the interior window sash, the $\mathrm{U}_{\mathrm{w}}<0.8 \mathrm{~W} / \mathrm{m}^{2} \mathrm{~K}$ value can be approached, which is a requirement for the windows of passive houses. With some exceptions, the suitable air tightness can also be achieved by rubber profiles at joints. However, it can cause complete airtightness in interior spaces, therefore ventilation is inevitable. In passive houses heat recovery ventilation is successfully applied. 


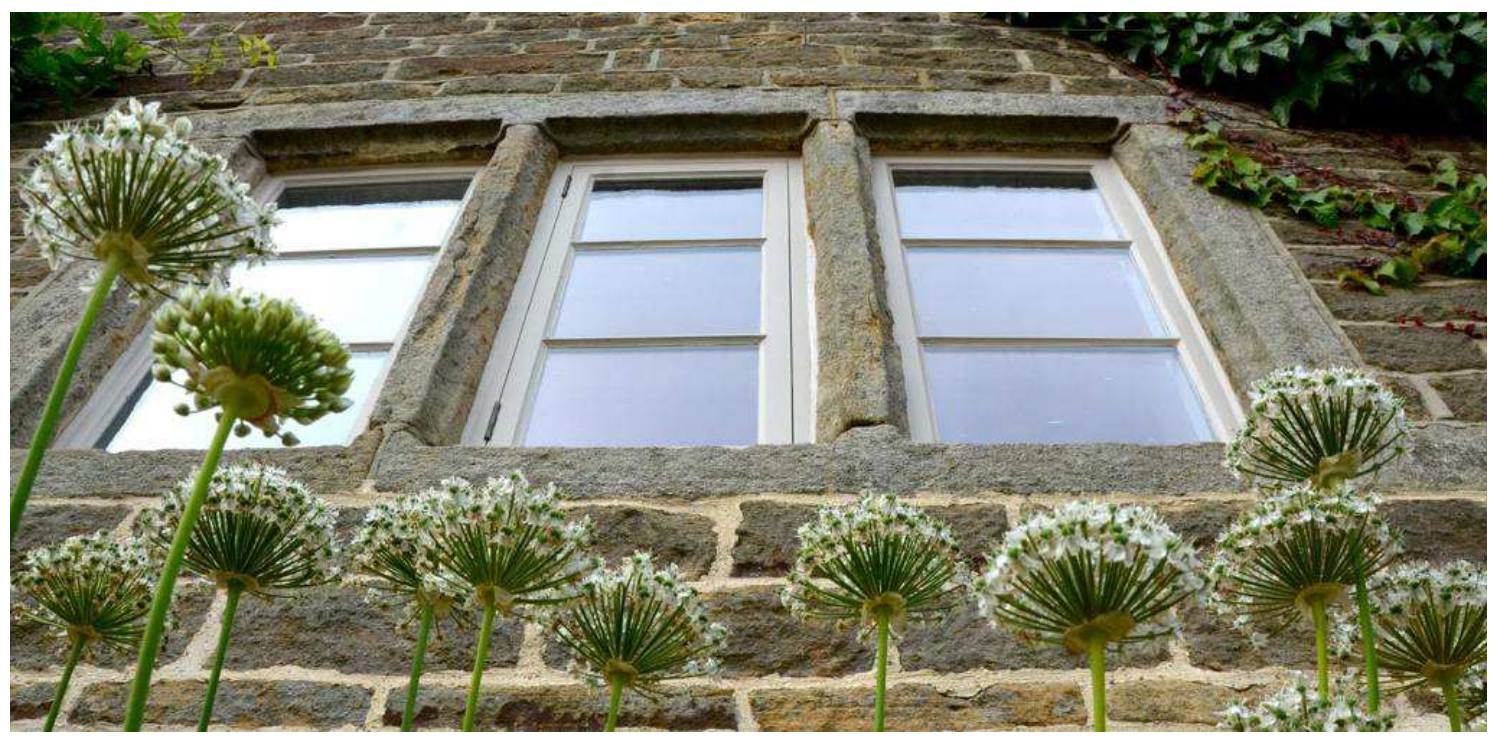

Figure 11. D10 Histoglass glazing - The Gate House - Hope Valley [18]

\section{Summary}

It is important to emphasize that the renovation of windows should be along with the thermal insulation of exterior walls. From the aspect of energy consumption it is important to consider the whole building, including slabs, floors as well as walls, since these are also significant cooling surfaces (Figure 3.). In case of historical buildings additional exterior thermal insulation often cannot be applied on facades, since it would cause the disappearance of the character of façade. (Figure 11.). In all cases, all the renovation or replacement methods of historic windows should be considered, since maintaining the appearance of historic buildings is a main priority.

\section{References}

[1] Trudeau P, Cambridge Historical Commission: Guidelines for Preservation and Replacement of Historic Wood Windows in Cambridge, 2009. May, www.cambridgema.gov/historic

[2] Lörinczi Zs, The protection of historic windows, Before window to change places, www.ablakprofilok.hu

[3] Szüts L, Historical analysis of the thermal characteristics of the window structures

[4] http://www.carpenter.hu/muemlek_jellegu_nyilaszarok

[5] Vuksanovic D, Murgul V, Vatin $\overrightarrow{\mathrm{N}}$, Pukhkal V, Optimization of microclimate in residential buildings, Applied Mechanics and Materials Vol. 680 (2014) pp 459-466

[6] Széll M, Reconstruction Design of Buildings, Transparent facade structures of energy-efficient and sustainable renovation

[7] Matias L, Goncalves L, Costa A, Santos Ca P, Cool façades, Thermal performance assessment using infrared thermography, Key Engineering Materials Vol. 634 (2015) pp 14-21 
[8] Olsen L, Radisch N, Thermal bridges in residential building in Denmark. Brno: KEA energeticka agentura s.r.o, Czech Republic, ISBN 80-902689-6-X, Available at: https://www.tc.cz/files/istec_publications/thermal-bridges.pdf (accessed 8 November 2014), 2002

[9] Blomberg, T, Heat conduction in two and three dimensions, Computer Modelling of Building, Physics Applications. Doctorate thesis, Lund University, Sweden, 1996

[10] Kusuda T, Bean J.W, Simplified methods for determining seasonal heat loss from uninsulated slab-on-grade floors. ASHRAE Transactions volume 90. part 1B, 611632,1984

[11] Kusuda T., Achenbach P.R., Numerical analysis of the thermal environment of occupied underground spaces with finite cover using a digital computer. ASHRAE Transactions volume 69, 439-452, 1963

[12] Rees, S.W., Zhou, Z., Thomas, H.R., Ground heat transfer: A numerical simulation of a full-scale experiment. Building and Environment 42, issue 3,1478-1488, 2007

[13] Széll M, Renovation of double-layer windows, Magyar Építéstechnika 2009/9

[14] Schittich Ch, Staib G, Balkow D, Schuler M, Sobek W, Glasbau Atlas (Birkhäuser Verlag, Basel, Boston, Berlin, 1998. ISBN 3-7643-5944-7)

[15] Tóth E, Window - People 2, Door-Window-Gate, Spektrum, Budapest, 2006

[16] Gänßmantel J, Geburtig G, Eßmann F, EnEV und Bauen im Bestand (HUSSMEDIEN GmbH, Verlag Bauwesen, Berlin, 2006. ISBN 3-345-00873-4)

[17] Bakonyi D, Becker G, Historical windows in the light of the new requirements

[18] Histoglass Glazing Systems The Gatehouse http://www.histoglass.co.uk/content/Project-Details/207

[19] EN ISO 10211:2007 Thermal bridges in building construction - Heat flows and surface temperatures - Detailed calculations (ISO 10211:2007). Brussels: CEN, 2007

[20] EN ISO 10456:2007 Building materials and products - Hygrothermal properties Tabulated design values and procedures for determining declared and design thermal values. Brussels: CEN, 2007

[21] EN ISO 6946:2007 Building components and building elements - Thermal resistance and thermal transmittance - Calculation method (ISO 6946:2007). Brussels: CEN, 2007 